\title{
Serum Homocystine Level in Women with Severe Preeclampsia
}

\author{
Shahnaz Akter Jahan, ${ }^{1}$ Nahid Reaz, ${ }^{2}$ Mirza Md. Asaduzzaman, ${ }^{3}$ Shafeya Khanam, ${ }^{4}$ Zebunnessa Parvin, ${ }^{5}$ \\ Dewan Shahida Banu ${ }^{6}$
}

\begin{abstract}
Objective: Though preeclampsia (PE) is an age-old disease, its pathology still remains obscure. Available epidemiological evidences suggest that PE is a disease of multiple theories. Recently serum homocystine level is considered as factor to be associated with preecampsia and the higher the level the greater is the severity of preeclampsia. The present study is aimed at investigating this hypothesized association.
\end{abstract}

Methodology: This case-control study was conducted over a period of 24 months from January 2012 to December 2013 in the Department of Obstetrics \& Gynaecology, Dhaka Medical College, Dhaka. Pregnant women admitted with severe preeclampsia were the case, while pregnant women attending at the antenatal clinic without preeclampsia were the controls. Severe preeclampsia was diagnosed by blood pressure $>$ $160 / 110 \mathrm{~mm}$ of $\mathrm{Hg}$ with proteinuria 3+ or more in dipstick test. The control group comprised of women of 24 40 weeks gestation, with blood pressure (both diastolic and systolic) remaining within normal limits without having any medical or obstetric complications. Data were analysed using software SPSS (Statistical Package for Social Sciences) version 16.0. The test statistics used to analyse the data were descriptive statistics, Chi-square $\left(\chi^{2}\right)$ Test, Student's t-Test and Receiver-operating characteristic (ROC) curve analysis.

Result: Around two-thirds of the patients in both groups were in the age range of 21-30 years with mean age of the cases and control being $25.8 \pm 5.2$ and $24.1 \pm 3.7$ years respectively $(p=0.108)$. Over three-quarters $(77.5 \%)$ of the patients in case group and $60.0 \%$ in control group belonged to middle class $(p=0.091)$. Majorities of the cases $(85.0 \%)$ and controls (90.0\%) were preterm (gestational age $<37$ weeks) with mean gestational age being $33.2 \pm 3.3$ and $32.3 \pm 3.5$ weeks in case and control groups respectively $(p>0.05)$. The patients in either group were predominantly primigravida. Seven $(17.5 \%)$ patients in the case group gave the history of past preeclampsia as opposed to none in the control group $(p=0.005)$. Family history of preeclampsia was reported by the case group alone $(p=0.027)$. Majority $(95.0 \%)$ of the cases had $3+$ proteinuria. Serum homocystine concentration was significantly raised $(15.7 \pm 8.3 \mu \mathrm{mol} / \mathrm{L})$ in case group than that in the control group $(6.7 \pm 1.3 \mu \mathrm{mol} / \mathrm{L})(p<0.001)$. Based on the receiver-operator characteristic (ROC) curve, serum homocysteine levels in pregnant women had the best area under the curve $(0.975$ or $97.5 \%)$ with sensitivity and specificity of the predictor variable being 92.5 and $77.5 \%$ respectively.

Conclusion: The study concluded that homocysteine levels are significantly elevated in patients with preeclampsia compared to the pregnant women without preeclampsia. Homocysteine may be of value in the monitoring of pregnancies to be complicated by preeclampsia.

Key words: Serum homocysteine, preeclampsia.

\section{Authors' information:}

${ }^{1}$ Dr. Shahnaz Akter Jahan, Assistant Registrar, MS (Obstetrics \& Gynaecology), Central Police Hospital, Rajarbag, Dhaka, 1000.

2 Dr. Nahid Reaz, Assistant Registrar, MS (Obstetrics \& Gynaecology), Central Police Hospital, Rajarbag, Dhaka, 1000.

${ }_{3}^{3}$ Dr. Shafeya Khanam, Assistant Professor, FCPS, MS (Obstetrics and Gynaecology), Faridpur Medical College \& Hospital, Faridpur.

${ }^{4}$ Dr. Mirza Md. Asaduzzaman, Junior Consultant, Gynae Oncology Department, National Institute of Cancer Research and Hospital (NICRH), Mohakhali, Dhaka.

${ }^{5}$ Dr. Zebunnessa Parvin, Associate Professor (Obstetrics and Gynaecology), MCPS, DGO, FCPS, Faridpur Medical College \& Hospital, Faridpur.

${ }^{6}$ Dr. Dewan Shahida Banu, Assistant Professor (Obstetrics \& Gynaecology), DGO, FCPS, Shaheed Tazuddin Ahmad Medical College, Gazipur.

Correspondence: Dr. Shahnaz Akter Jahan, Cell Phone: +880 1733292346, E-mail:mahbubhtl@gmail.com 


\section{INTRODUCTION:}

Preeclampsia (PE) is a multisystem disorder of unknown etiology, unique to pregnancy with the onset after 20 weeks of gestation. It is considered severe if blood pressure and proteinurea are increased substantially when maternal multiorgan failure, coagulopathy and maternal and fetal death may occur. ${ }^{1-3}$ It complicates $5-7 \%$ of all pregnancies; ${ }^{4} 5-10 \%$ of which are severe. ${ }^{5}$ In developing countries, PE complicates $4.4 \%$ of all deliveries and may be as high as $18 \%$ in some settings in Africa. In Bangladesh the incidence of PE ranges from 10 to $15 \%$ of all deliveries, ${ }^{6}$ but only $2.3 \%$ of women end their pregnancy under medical supervision (whether it is abortion or delivery). ${ }^{7}$ In a baseline survey of emergency obstetric care (EOC) situation in Bangladesh, 5\% of total obstetrical admissions in health facilities were due to PE and Eclampsia. ${ }^{7}$ As there are approximately 3.6 million births occur each year in Bangladesh, over 100,000 women develop eclampsia per year. ${ }^{5}$

The clinical condition was first discovered over 100 years ago, but still its pathology remains obscure. Available epidemiological evidences suggest that $P E$ is a disease of multiple theories. Among them genetics, immunologic, circulatory, uterine vascular changes and endothelial dysfunction are important. Current hypothesis for the pathogenesis of PE states that immunological disturbance causes abnormal placentaion resulting in decreased placental perfusion and release of various circulatory factors from placenta to both maternal and fetal circulation. These may lead to endothelial cell injury and vascular pathology with changes in vasomotor tone and coagulation. Studies show that vascular endothelial damage and dysfunction is present in uteroplacental bed in PE. ${ }^{8,9}$ Most recently homocysteine has been claimed as a factor for vascular endothelial cell injury in preeclampsia. ${ }^{10}$ Homocysteine is a sulfur containing amino acid derived from the metabolic demethylation of dietary methionine, which is abundant in animal protein. It is present in plasma in four forms, ${ }^{11}$ and is eliminated from the body via conversion into cystathion by a reaction catalyzed by vitamin B6 and Methionine catalyzed by vitamin B12 and folic acid as a cofactor. ${ }^{12}$

The term 'total plasma (or serum) homocysteine' (tHcy) refers to the combined pool of all four forms of homocysteine. An abnormal tHcy is defined by an arbitrary cut-off (e.g., 95 percentile) in the distribution of concentrations found in the 'normal population' in much the same way as hypertension and hypercholesterolaemia have been defined. Among fasting individuals 'normal' tHcy commonly ranges from 5 to 15 micro mol/L. ${ }^{13}$ Homocysteine is found in low concentration in all tissues under normal condition. ${ }^{14}$ The concentration of plasma homocysteine is regulated by several factors. These include genetically determined metabolic enzyme alteration, nutritional status (vitamin B12 and folate deficiency), underlying diseases, certain medications, age and pregnancy; of them, pregnancy is the only factor that specifically decreases the concentration of plasma homocysteine. ${ }^{15}$

Levels of maternal serum homocystetne normally decrease with gestation, either due to a physiological response to the pregnancy, increase in estrogen, hemodilution from increased plasma volume or increased demand for methionine by both the mother and the fetus. ${ }^{16}$ Elevated plasma homocysteine is, therefore, recognized as an important risk factors for preeclampsia and eclampsia. ${ }^{17}$ There is strong evidence that homocysteine correlates with increased risk of cardiovascular disease, stroke and a range of other thromboembolic conditions and events including PE, although it is not clear whether the association is causal or a manifestation of the disease process. Causal relation between hyperhomocysteinemia and PE in Irish population had been observed by Cotter et al. ${ }^{18}$ They concluded that elevated plasma homocysteine level in early pregnancy is associated with a 4-fold increased risk for development of non-severe PE and 3-fold increased risk of severe PE. Several other studies have also indicated that homocysteine concentrations are increased in women with preeclampsia. ${ }^{19}$ But there are a few reports concerning hyperhomocysteinemia in patients with eclampsia. ${ }^{20,21}$ Hyperhomocysteinemia is 
treatable by supplementation of vitamins like vitamins B6, B12 and folic acid. So hyperhomocysteinemia, if detected in early pregnancy, taking supplementation might help substantially to reduce the occurrence of preeclampsia and adverse pregnancy outcome. The present study is, therefore, designed to investigate the serum homocysteine level and to evaluate its association with severity of preeclampsia in Bangladeshi population. The data obtained from the study may be useful in deciding whether plasma homocysteine as a screening test in early pregnancy could predict the development of PE and its severity.

\section{MATERIALS AND METHODS:}

This case-control study was conducted over a period of 24 months from January 2012 to December 2013 in the Department of Obstetrics \& Gynaecology, Dhaka Medical College, Dhaka. Pregnant women admitted with severe preeclampsia, gestational age between 24 and 40 weeks were the case, while pregnant women (between 24-40 weeks) attending at the antenatal clinic without preeclampsia were the controls. Severe preeclampsia was diagnosed by blood pressure $>160 / 110 \mathrm{~mm}$ of $\mathrm{Hg}$ with proteinuria 3+ or more in dipstick test. The control group had both systolic and diastolic blood pressures within normal limits without any medical or obstetric complications. As 'normal' tHcy in fasting individuals commonly ranges from 5 to 15 micro $\mathrm{mol} / \mathrm{L}$, higher fasting values were classified arbitrarily as moderate (16-30 micro mol/L), intermediate (31-100 micromol/L), and severe (>100 micro mol/L) hyperhomocysteinaemia. Data were analysed using software SPSS (Statistical Package for Social Sciences) version 16.0. The test statistics used to analyse the data were descriptive statistics, Chi-square $\left(\chi^{2}\right)$ Test, Student's t-Test and Receiver-operating characteristic (ROC) curve analysis. The level of significance was set at 0.05 and $p$-value $<0.05$ was considered significant.

\section{RESULTS:}

Age distribution shows that two-thirds of the patients in both groups were in the age range of 21-30 years with mean age of the patients in case and control groups being $25.8 \pm 5.2$ years and $24.1 \pm 3.7$ years respectively $(p=0.108)$. In terms of occupation, housewives formed the main bulk in both case and control groups $(90.0 \%$ and $82.5 \%$ respectively). Over three-quarters $(77.5 \%)$ of the patients in case group and $60.0 \%$ in control group belonged to middle class ( $p=$ 0.091) (Table I). Majorities of the cases $(85.0 \%)$ and controls $(90.0 \%)$ were preterm (gestational age $<37$ weeks) with mean gestational age being $33.2 \pm 3.3$ and $32.3 \pm 3.5$ weeks in case and control groups respectively ( $p=0.339)$.

\begin{tabular}{|c|c|c|c|}
\hline \multirow[b]{2}{*}{ Demographic characteristic } & \multicolumn{2}{|c|}{ Group } & \multirow[b]{2}{*}{ p-value } \\
\hline & $\begin{array}{c}\text { Case } \\
(n=40)\end{array}$ & $\begin{array}{l}\text { Control } \\
(n=40)\end{array}$ & \\
\hline \multicolumn{4}{|l|}{ Age (in year)* } \\
\hline$\leq 20$ & $8(20.0)$ & $14(35.0)$ & \\
\hline $21-25$ & $16(40.0)$ & $20(50.0)$ & \\
\hline $26-30$ & $12(30.0)$ & $6(15.0)$ & \\
\hline$>30$ & $4(10.0)$ & $0(0.0)$ & \\
\hline Mean $\pm S D^{\#}$ & $25.8 \pm 5.26$ & $24.15 \pm 3.69$ & 0.108 \\
\hline \multicolumn{4}{|l|}{ Occupational status* } \\
\hline Housewife & $36(90.0)$ & $33(82.5)$ & \multirow{2}{*}{0.330} \\
\hline Job Holder & $4(10.0)$ & $7(17.5)$ & \\
\hline \multicolumn{4}{|l|}{ Socioeconomic condition* } \\
\hline Poor & $9(22.5)$ & $16(40.0)$ & \\
\hline Middle Class & $31(77.5)$ & $24(60.0)$ & 0.091 \\
\hline Rich & $0(0.0)$ & $0(0.0)$ & \\
\hline
\end{tabular}

Figures in the parentheses indicate corresponding \%;

*Chi-square Test $\left(\chi^{2}\right)$ was done to analyse the data.

\# Data were analyzed using Unpaired t-Test and were presented as mean \pm SD.

\begin{tabular}{|c|c|c|c|}
\hline \multirow[b]{2}{*}{ Obstetric variables* } & \multicolumn{2}{|c|}{ Group } & \multirow[b]{2}{*}{$\mathrm{p}$-value } \\
\hline & $\begin{array}{l}\text { Case } \\
(n=40)\end{array}$ & $\begin{array}{l}\text { Control } \\
(n=40)\end{array}$ & \\
\hline \multicolumn{4}{|l|}{ Gestational age (weeks) } \\
\hline$<37$ (preterm) & $34(85.0)$ & $36(90.0)$ & \multirow{2}{*}{0.339} \\
\hline$\geq 37$ (term) & $6(15.0)$ & $4(10.0)$ & \\
\hline \multicolumn{4}{|l|}{ Gravida } \\
\hline Primi & $22(55.0)$ & $27(67.5)$ & \multirow{2}{*}{0.251} \\
\hline Multi & $18(45.0)$ & $13(32.5)$ & \\
\hline History of past preeclampsia & $7(17.5)$ & $0(0.00)$ & 0.005 \\
\hline History of preeclampsia in family & $5(12.5)$ & $0(0.00)$ & 0.027 \\
\hline
\end{tabular}

Figures in the parentheses indicate corresponding \%;

*Chi-square Test $\left(\chi^{2}\right)$ was done to analyse the data. 
More than half (55\%) of the patients in the case group and two-thirds (67.5\%) in the control group were primigravida $(p=0.251)$. Seven $(17.5 \%)$ patients in the case group gave the history of past preeclampsia as opposed to none in the control group ( $p=0.005)$. Family history of preeclampsia was also solely reported by the case group ( $p=$ 0.027) (Table II). The mean systolic blood pressure was $169.0 \pm 10.3 \mathrm{mmHg}$ and 115.0 $\pm 17.0 \mathrm{mmHg}$ in case and control respectively ( $p<$ 0.001 ), while the mean diastolic blood pressure was $115.1 \pm 5.9$ and $68.0 \pm 11.0 \mathrm{mmHg}$ respectively ( $p<0.001$ ) (Table III). Majority $(95.0 \%)$ patients had $3+$ proteinuria and $5.0 \%$ $2+$ proteinuria (Fig 1). Serum homocystine concentration was significantly raised (15.7 \pm 8.3 $\mu \mathrm{mol} / \mathrm{L})$ in case group than that in control group $(6.7 \pm 1.3 \mu \mathrm{mol} / \mathrm{L})(\mathrm{p}<0.001)$ (Table IV). Of the 40 cases, $16(40 \%)$ had hyperhomocysteinaemia (serum homocystine $>15 \mathrm{mmol} / \mathrm{L}$ ), while none of the control had raised serum homocystine.

\begin{tabular}{|c|c|c|c|}
\hline \multirow[b]{2}{*}{ Blood pressure " } & \multicolumn{2}{|c|}{ Group } & \multirow[b]{2}{*}{$\mathrm{p}$-value } \\
\hline & $\begin{array}{c}\text { Case } \\
(n=40)\end{array}$ & $\begin{array}{l}\text { Control } \\
(n=40)\end{array}$ & \\
\hline Systolic BP (mmHg) & $169.0 \pm 10.3$ & $115.0 \pm 17.0$ & 0.001 \\
\hline Diastolic BP (mmHg) & $115.13 \pm 5.9$ & $68.0 \pm 1.0$ & 0.001 \\
\hline
\end{tabular}

\# Data were analyzed using Unpaired $\mathbf{t}$-Test and were presented as mean \pm SD.

\begin{tabular}{|c|c|c|c|}
\hline \multicolumn{4}{|c|}{$\begin{array}{l}\text { TABLE IV. Distribution of the study patients by serum } \\
\text { homocysteine concentration }(n=80) \text {. }\end{array}$} \\
\hline \multirow[b]{2}{*}{$\begin{array}{l}\text { Serum homocysteine } \\
\text { concentration }\end{array}$} & \multicolumn{2}{|c|}{ Group } & \multirow[b]{2}{*}{$\mathrm{p}$-value } \\
\hline & $\begin{array}{l}\text { Case } \\
(n=40)\end{array}$ & $\begin{array}{l}\text { Control } \\
(n=40)\end{array}$ & \\
\hline Serum Homocystine $(\mu \mathrm{mol} / \mathrm{L})$ & $15.7 \pm 8.3$ & $6.7 \pm 1.3$ & 0.001 \\
\hline Range & $7.46-38.2$ & $4.06-8.39$ & \\
\hline
\end{tabular}

Figures in the parentheses indicate corresponding \%;

\# Data were analyzed using Unpaired $t$-Test and were presented as mean \pm SD.

TABLE V. Receiver-operator characteristic (ROC) curve of serum homocysteine levels for prediction of preeclampsia.

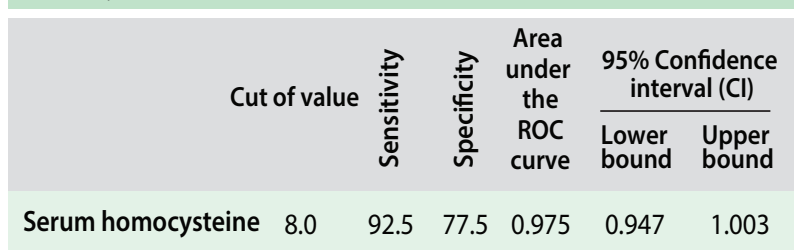

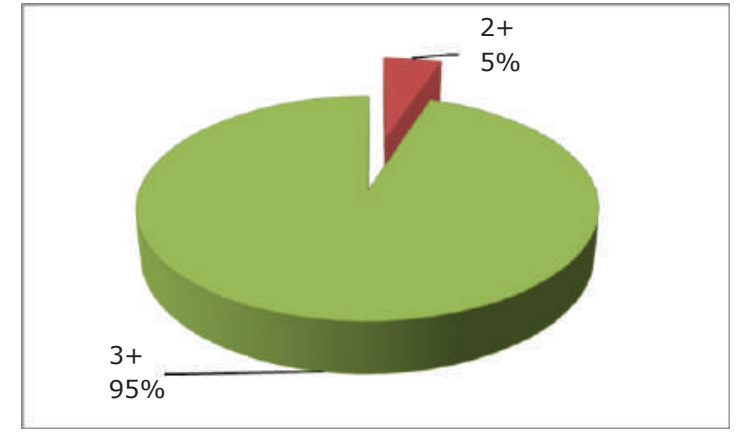

Fig 1: Distribution of the cases by urinary protein $(n=40)$

Receiver-operator characteristic curve was constructed using serum homocysteine value of the participating women, which gives a cut off value of $>8.0$ as the value with a best combination of sensitivity $(92.5 \%)$ and specificity $(77.5 \%)$ for the prediction of preeclampsia. Based on the ROC curve serum homocysteine levels had the best area under curve 0.975 or $97.5 \%$. (Table V) (Fig 2).

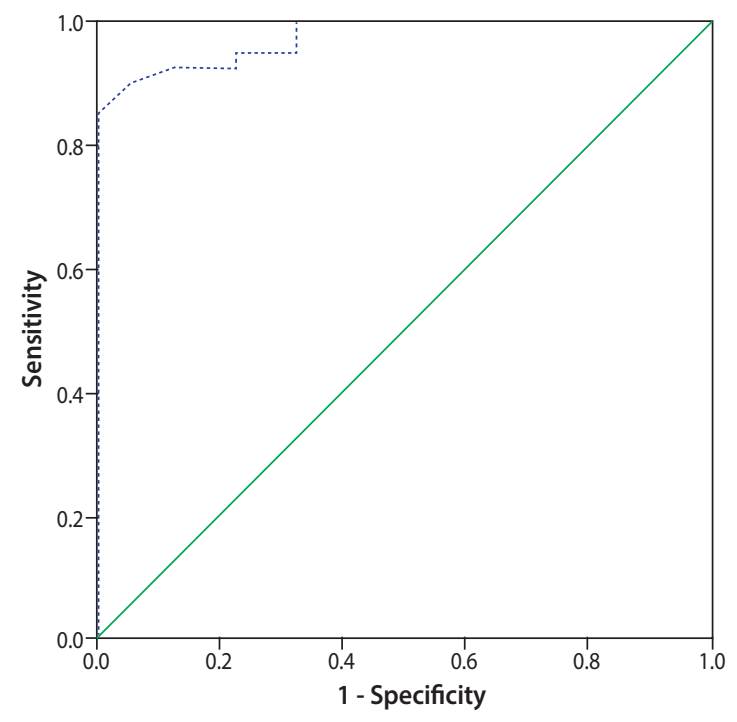

Figure 2: Receiver-operator characteristic curve of serum homocysteine levels.

\section{DISCUSSION}

In the present study the case and control groups were almost similar in terms of age distribution (25.8 \pm 5.2 vs. $24.1 \pm 3.7$ years, $p=0.108)$. Majorities of the cases $(85.0 \%)$ and controls $(90.0 \%)$ were preterm (gestational age < 37 weeks) with mean gestational age being $33.2 \pm$ 3.3 and $32.3 \pm 3.5$ weeks in case and control groups respectively $(p>0.05)$. Past history and 
family history of preeclampsia were reported by few patients in the case group alone $(p=0.027)$. In this series most (95.0\%) of the preeclamptic patients had severe proteinuria $(3+)$.

Javadi et al.22 showed the mean age of severe preeclampsia group and control group to be 27.7 \pm 5.8 and $26.5 \pm 5.8$ years respectively, which is consistent with the current study. Similarly, Sangeeta et al. ${ }^{23}$ mentioned that maximum number of the cases was in the age group of 21-25 years. In another study Franceschini et al. ${ }^{24}$ reported that women developing preeclampsia were somewhat younger than the controls (29.8 \pm 0.7 and $31.8 \pm 0.5$ years, $\mathrm{p}<0.05)$. Thilaganathan et al. ${ }^{25}$ showed mean age of the preeclamptic and healthy pregnant women to be $29.6 \pm 5.7$ and $31.9 \pm 5.2$ years respectively. Similarly, Kristensen et al. ${ }^{26}$ observed mean age of case and control groups to be $32 \pm 5.0$ and $32 \pm 4.6$ years respectively. In our study majority of subjects in both groups was middle class. Contrary to this finding, Sangeeta et al. ${ }^{23}$ mentioned that majority of the women in their study were from the lowest socioeconomic strata $(60.0 \%)$. Ingec et al. ${ }^{20}$ reported that preeclampsia occurs more often in primiparas which compares well with the findings of the present study. In the present study majorities of the cases $(85.0 \%)$ and controls $(90.0 \%)$ were preterm (gestational age < 37 weeks) with mean gestational age being 33.2 \pm 3.3 and $32.3 \pm 3.5$ weeks in case and control groups respectively ( $p>0.05)$. However, Franceschini et al. ${ }^{24}$ observed higher mean gestational age in their study (35.2 \pm 0.4 and 39.5 \pm 0.1 weeks in case and control groups respectively). Kristensen et al. ${ }^{26}$ showed even higher mean gestational age (39.4 weeks in control and 38.7 weeks in mild preeclamptic group) in their study.

In the present study serum homocystine concentration was significantly raised (15.7 \pm 8.3 $\mu \mathrm{mol} / \mathrm{L})$ in case group than that in control group $(6.7 \pm 1.3 \mu \mathrm{mol} / \mathrm{L})(p<0.001)$. However, as none of the control group exhibited abnormally raised serum homocystine ( $>15 \mathrm{mmol} / \mathrm{L}$ ), the risk of having severe preeclmpsia in pregnant women with raised homocystine could not be calculated.
Dekker et al. ${ }^{27}$ demonstrated that serum homocysteine could be seven times higher in women with severe preeclampsia compared to the normal pregnant women. Similarly, Makedos et al. ${ }^{28}$ mentioned that homocysteine concentration was significantly higher in preeclamptic patients than that in the control group (11.11 vs. 6.40 $\mu \mathrm{mol} / \mathrm{L}, \mathrm{p}<0.001)$. In another study Powers et al. ${ }^{29}$ found a significant difference in the serum levels of homocysteine between preeclamptics and controls (9.0 vs. $7.0 \mu \mathrm{mol} / \mathrm{L}, \mathrm{p}<0.05)$. Furthermore, they found a marker of endothelial dysfunction, with homocysteine. Several other studies have found a positive association of homocysteine with preeclampsia. ${ }^{30-32}$ However, these findings were not confirmed by other investigators possibly due to different patient characteristics. ${ }^{19,20,33}$ Another systematic review (25 primary articles, 3,649 women), intended to assess the hypothesized mechanism of homocysteine in preeclampsia, showed a positive association of homocysteine serum level with preeclamptic patients in all but one of the review articles, with a weighted mean difference of 2.50 $\mu \mathrm{mol} / \mathrm{L}(95 \%$ CI 1.82- 3.17, P < 0.001) between preclamptic women and healthy pregnant women. ${ }^{34}$ In a very recent study ${ }^{23}$ the level of serum homocysteine was observed to be higher in the case group compared to control group (10.3 \pm 2.5 vs. $3.5 \pm 1.2 \mu \mathrm{mol} / \mathrm{L}, \mathrm{p}=0.001)$. The above findings are comparable to those reported by Sanchez et al. ${ }^{35}$ and Harma et al. ${ }^{36}$ Javadi et al. ${ }^{22}$ who showed that the mean serum homocysteine to be $8.9 \pm 4.1 \mu \mathrm{mol} / \mathrm{L}$ in patients with severe preeclampsia and $5.5 \pm 1.6 \mu \mathrm{mol} / \mathrm{L}$ in control group patients $(p<0.001)$. Acilmis et al. ${ }^{37}$ showed that maternal and fetal serum homocysteine levels to be significantly higher in severe preeclampsia group than those in mild preeclampsia and healthy controls, suggesting that level of serum homocysteine is increased with severity of preeclampsia.

In this study based on the ROC curve, the serum homocysteine levels had the best area under the curve $(0.975$ or $97.5 \%)$ with sensitivity and specificity of the predictor variable being 92.5 and $77.5 \%$ respectively at a cut off value $>8 \mu \mathrm{mol} / \mathrm{L}$. However, Pandya et al. ${ }^{38}$ in a ROC curve analysis 
showed that the area under the curve (AUC) obtained was $54.0 \%$ with sensitivity and specificity of serum homocystine being 61.1 and $49.7 \%$ suggesting that the diagnostic accuracy of plasma homocysteine levels in predicting preeclampsia is inappreciably low.

\section{CONCLUSION}

The study concluded that homocysteine levels are significantly elevated in patients with preeclampsia compared to the pregnant women without preeclampsia. Homocysteine may be of value in the monitoring of pregnancies to be complicated by pre-eclampsia.

\section{REFERENCES}

1. Friedman SA, Taylor RN, Roberts JM. Pathophysiology of preeclampsia. Clinics in Perinatology 1991;18(4): 661-82.

2. Barron WM. The syndrome of preeclampsia. Gastroenterologyh Clinic North America 1992;21(4):851-72.

3. Wanger LK. Diagnosis and Management of preeclampsia. American Family Physician 2004;70:2317-24.

4. Miller DA. Hypertension in Pregnancy. In: DeCherney AH, Goodwin TM, Natha L, Laufer N, editors. Current Diagnosis \& Treatment Obstetrics and Gynecology. $10^{\text {th }}$ ed. McGraw-Hill, New York; 2007. p. 318-27.

5. Robson SC. Hypertension and renal disease in pregnancy. In: Emonds DK, editor. Dewhurst's Text Book of Obstetrics and Gynaecology for Post-graduates. $6^{\text {th }}$ ed. London: Blackwell Science Publication. p.166-69.

6. Khatoon MS. Clinical profile and management of ecalmpsia in SSMCH and MF, Dhaka. Bangladesh College of Physician and Surgeons (Dissertation). 1992.

7. Yesmin HA, Rahman MH, Chowdhury FK. Baseline survey for assessment of emergency obstetrics care service in Bangladesh. Bangladesh Institute of Research for promotion of Essential and Reproduction health and Technologies (BIRPERTH), 1995.

8. Chesley LC. Hypertensive Disorders in Pregnancy. New York: Appleton-Century- Crofts; 1978.

9. Wang J, Mimuro S, Labound R, Trudinger B, Wang $X L$. Elevated levels of lipoprotein in women with preeclampsia. Am J Obstet Gynaecol 1998;178:146-49.

10. Wang J, Trudingl BJ, Duarte N, Wikhen DE, Wang XL. Elevated circulating homocysteine levels in placental vasclar disease and associated preeclampsia', RCOG 2000. Br J Obst \& Gynecol 2000;107:932-34.

11. Ueland PM. Homocysteine species as components of plasma redox thiol status. Clin Chem 1995;41(3):
$340-42$.

12. Calle M, Usandizaga R, Sancha M. Homocysteine, folie acid and B-group vitamins in obstetrics and Gynaecology. European Journal of Obstetrics and Gynaecology and Reproductive Biology 2002; 107:125-34.

13. Refsum $H$, Fiskerstrand $T$, Guttormsen $A B$, Ueland PM. Assessment of homocysteine status. J Inher Metab Dis 1997;20:286-94.

14. Finkelstein JD. The metabolism of homocysteine: Pathways and Regulation. European Journal of Paediatrics 1998;157(2):40-44.

15. Powers RW, Evans RW, Majors AK, Ojimba JI, Ness RB, Crombleholme WR, et al. Plasma homocysteine concentration is increased in preeclampsia and is associated with evidence of endothelial activation. Americal Journal of Obstetrics and Gynaecology 1998;179(6):1605-11.

16. Walker MC, Smith GN, Perkins SL, Kelly EJ, Garner PR. Changes in homocysteine levels during normal pregnancy. American Journal of Obstetrics and Gynaecology 1999;180(3):660-64.

17. Niyazi T, Hasnu C, Gurkan C, Oguz O, Ahmet A. The correlation between plasma homocysteine and malondialdehyde level in preeclampsia. Journal of Neuroendocrinology 2003;24(6):446-48.

18. Cotter AM, Molloy AM, Scott JM, Daly SF. Elevated plasma homocysteine in early pregnancy: A risk factor for the development of severe preeclampsia. American Journal of Obstetrics and Gynaecology 2003;189:391-6.

19. Vollset SE, Refsum $H$, Irgens LM, Emblem BM, Tverdal A, Gjessing HK et al. Plasma total homocysteine, pregnancy complications and adverse pregnancy outcomes: The Hordaland Homocysteine Study. American Journal of Clinical Nutrition 2000;71:962-68.

20. Ingec M, Borekci B, Kadanali S. Elevated plasma homocysteine concentration in severe preeclampsia and eclampsia. Tohoku J Exp Med 2005;206:225-31.

21. Gurbuz A. Elevated plasma homocysteine level in preeclampsia and eclampsia. International Journal of Gynaecolgy and Obstetrics 2004:165-66.

22. Javadi HSE, Ghorbali F, Sarookhani M, Javadi A, Mashrabi $\mathrm{O}$. The relationship between the level of homocysteine in mother's serum and the intensity of preeclampsia. Life Sci 2012;9(4):1247-49.

23. Sangeeta N, Shaini L, Basar G, Devi S, Chhuangi V, Kanti Mandal K, et al. Serum Uric Acid and Homocysteine as Predictors of Pre-eclampsia. Metab 2013;4:259.

24. Franceschini N, Qiu C, Barrow V, Williams MA. 
Cystatin C and Preeclampsia: A Case Control Study. Renal Failure 2008;30:89-95.

25. Thilaganathan BT, Papageorghiou A, Melchiorre K, Sheldon J. Raised Maternal Serum Cystatin C: An Early Pregnancy Marker for Preeclampsia. Reproductive Sciences 2009; 16:788.

26. Kristensen K, Wide-swensson D, Schmidt C, Blirup-jensen $S$, Lindstro MV, Strevens $H$ et al. Cystatin C, b-2-microglobulin and b-trace protein in pre-eclampsia. Acta Obstetricia et Gynecologica 2007;86:921-26.

27. Dekker AG, DeVries JIP, Doelitzsch PM. Underlying disorders associated with severe early onset preeclampsia. Am J Obstet Gynecol 1995;173:1042-48.

28. Makedos G, Papanicolaou A, Hitoglou A, Kalogiannidis I, Makedos A, Vrazioti $V$ et al. Homocysteine, folic acid and $B 12$ serum levels in pregnancy complicated with preeclampsia. Arch Gynecol Obstet 2007;275:121-24.

29. Powers RW, Evans RW, Ness RB, Crombleholme WR, Roberts JM. Homocysteine and cellular fibronectin are increased in preeclampsia, not transient hypertension of pregnancy. Hypertension in Pregnancy 2001;20(1):69-77.

30. Baksu A, Taskin M, Goker N, Baksu B, Uluocak A. Plasma homocysteine in late pregnancies complicated with preeclampsia and in newborns. Am J Perinatol 2006;23:31-35.

31. Daly S, Cotter A, Molly AE, Scott J. Homocysteine and folic acid: implications for pregnancy. Semin Vasc Med 2005; 5:190-200.
32. Fayder MR, Yussef M, Odah MM. Hyperhomocysteinemia is A risk marker for development of maternal preeclampsia. Boll Chim Farm 2004;143:281-87.

33. Fernandez M, Fernandez G, Diez-Ewald M. Plasma homocysteine concentration and its relationship with the development of preeclampsia, EVects of prenatal administration of folic acid. Invest Clin 2005;46:187-95.

34. Mignini LE, Latha PM, villar J, Kilby MD, Carroli G, Khan $\mathrm{KS}$, et al. Mapping the theories of preeclampsia:The role of homocysteine. Obstrics \& Gynecology 2005; 105(2):411-25.

35. Sanchez SE, Zhang $C$, Rene Malinow $M$, Ware-Jauregui S, Larrabure G, et al. Plasma folate, vitamin B(12), and homocyst(e)ine concentrations in preeclamptic and normotensive Peruvian women. Am J Epidemiol 2001;153:474-80.

36. Harma M, Harma M, Kocyigit A. Correlation between maternal plasma homocysteine and zinc levels in preeclamptic women. Biol Trace Elem Res 2005;104:97-105.

37. Acilmis YG, Dikensoy E, Kutlar AI, Balat O, Cebesoy FB, Ozturk $E$ et al. Homocysteine, folic acid and vitamin B12 levels in maternal and umbilical cord plasma and homocysteine levels in placenta in pregnant women with pre-eclampsia. J Obstet Gynaecol Res 2011;37(1):45-50.

38. Pandya B, Awan N, Shah S, Pande R, Prasad V, Myers M, Robertson I. Raised Plasma Homocysteine Concentration in Pregnancy as a Predictor of Preeclampsia. University of Liverpool. Conference: RCOG World Congress [Internet]. 2013 [Cited 19/02/2017 3:23:03 PM] Available 